\title{
ERRATUM: Inhibitors of histone deacetylases induce tumor-selective apoptosis through activation of the death receptor pathway
}

A Insinga, S Monestiroli, S Ronzoni, V Gelmetti, F Marchesi, A Viale, L Altucci, C Nervi, S Minucci \& P G Pelicci

Nat. Med. 11, 71-76 (2005)

In Fig. 2a, the second and fourth graphs in the lower row should be marked Tnfrsf10b and Tnfrsf6, respectively. In Fig. 2b, the gene symbol Tp53 should read $T p 53^{-1-}$.

In Methods, the administration of VPA and TSA for in vivo antitumor activity studies should be "intraperitoneally for $21 \mathrm{~d}$ at a dose of $400 \mathrm{mg} / \mathrm{kg}$ twice daily and $1 \mathrm{mg} / \mathrm{kg} / \mathrm{d}$, respectively."

ERRATUM: Inhibition of respiratory syncytial virus infection with intranasal siRNA nanoparticles targeting the viral NS1 gene

W Zhang, H Yang, X Kong, S Mohapatra, H San Juan-Vergara, G Hellermann, S Behera, R Singam, R F Lockey \& S S Mohapatra Nat. Med. 11, 56-62 (2005)

The open square in Fig. 1 b refers to results from A549 cells, not from uninfected cells.

ERRATUM: The clock gene Per2 influences the glutamatergic system and modulates alcohol consumption

R Spanagel, G Pendyala, C Abarca, T Zghoul, C Sanchis-Segura, M C Magnone, J Lascorz, M Depner, D Holzberg, M Soyka, S Schreiber, F Matsuda, M Lathrop, G Schumann \& U Albrecht

Nat. Med. 11, 35-42 (2005)

In the print version of this article, Figures $\mathbf{4 d}, \mathbf{4 f}$ and $\mathbf{5 a}$ were inadvertently truncated. The correct versions appear below.

$4 d$

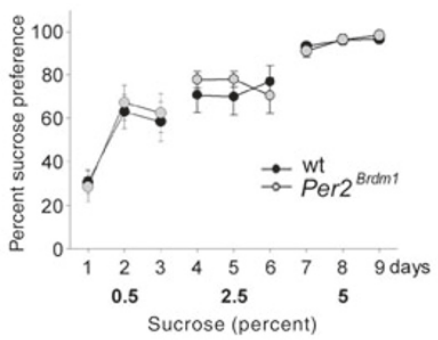

$4 f$

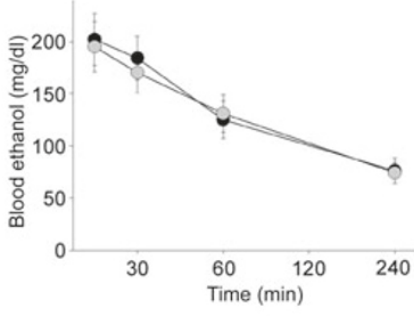

$5 a$

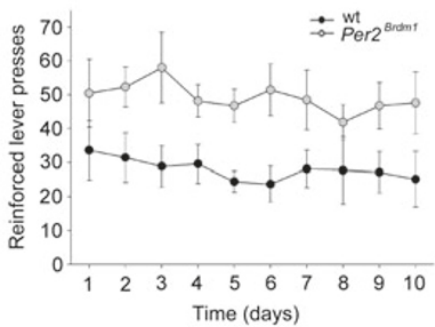

